\title{
15. LITHOLOGIC FACIES AND CLAY MINERAL ASSEMBLAGES IN MESOZOIC AND CENOZOIC SEDIMENTS RECOVERED BY DEEP SEA DRILLING PROJECT LEG 71 IN THE SOUTH ATLANTIC .
}

\author{
P. P. Timofeev, U.S.S.R. Academy of Sciences, Moscow, U.S.S.R. \\ and
}

N. V. Renngarten and M. A. Rateev, Geological Institute of the U.S.S.R. Academy of Sciences, Moscow, U.S.S.R.

\begin{abstract}
The distribution of clay minerals, determined by X-ray diffraction, is given for Jurassic to Holocene sediments recovered at DSDP Sites 511 and 513 in the Southwest Atlantic. These data, plus the lithologic and paleoenvironmental information gathered by the shipboard scientists, are used to subdivide the sedimentary sequence into genetic lithologic facies labeled series, seven for Site 511 and two for Site 513. Sediments of these series reflect the main historical and paleoenvironmental events which other means of study have determined to affect this region; particularly important was the opening of the South Atlantic during the Early Cretaceous.
\end{abstract}

\section{INTRODUCTION}

Core material from Sites 511 on the Falkland Plateau and 513 in the Argentine Basin (Fig. 1) were studied to establish lithologic and mineralogical criteria for the division of Mesozoic-Cenozoic deposits and to note the main trends in their sedimentation history. This is determined by lithologic and facial analyses, detail study of the composition of sediments, their structural and textural peculiarities, and the mineralogy of the clay component. Sediment facies were determined following the classification by P. P. Timofeev (1969). The clay minerals were investigated predominantly by use of X-ray diffractometry.

\section{METHODS}

Fractions of $<1 \mu \mathrm{m}$ and $<10 \mu \mathrm{m}$ were studied by radiography after treatment by $0.1 \mathrm{~N} \mathrm{HCl}$ (without heating) and washing in distilled water. The structural varieties were identified on the X-ray diffractograms obtained by a DRON-1 diffractometer using $\mathrm{CuK} \alpha$ radiation under $35 \mathrm{kV}, 20 \mathrm{~mA}$. The scanning rate was $2^{\circ} \mathrm{r} / \mathrm{min}$. X-ray diffractograms (Figs. 2-4) were obtained for three states of the sample: (1) natural or air dry; (2) glycerol-saturated and (3) heated at $550^{\circ} \mathrm{C}$. The identification of clay minerals, including the group of mixed-layer minerals, was based on the works by MacEwan (1955), Reynolds (1968), Drits and Sakharov (1976), and Gradusov (1976).

\section{RESULTS}

The most widespread minerals in the clay fraction $<1 \mu \mathrm{m}$ in the sequences were varieties belonging to or related to the smectite group, i.e., intensely swelling, mixed-layer minerals of the montmorillonite-illite type (M-i) with abundant swelling packets (M).

The smectite group was subdivided into three varieties: Na-montmorillonite (with $d_{001}=12.5 \AA$ for natural mounts; $d=17.7 \AA$ for glycerol-saturated mounts; and $d=10 \AA$ for mounts heated at $550^{\circ} \mathrm{C}$ ); Ca-montmorillonite (parameters are, respectively, 15.2, 17.7, and $10 \AA$ ), and $\mathrm{Mg}, \mathrm{Ca}$ varieties of smectites (parameters $14.7,17.7$, and $10 \AA$, respectively). In three cases where the montmorillonite was identified without indi- cating the structural variety, it corresponds to the usual stable Al-montmorillonite from the smectite group.

Four types of structures were identified in the mixedlayer minerals in which there were irregular alternations between the montmorillonite and illite packets:

1) An intensely swelling mixed-layer (M-i) mineral with few Al-mica packets, relatively resistant to redeposition and most abundant both in Hole 511 and Hole 513 (where it occurs with illite as an essential admixture). It is identified by an asymmetric peak $d_{001}=12.3,13-14$ up to $14.7 \AA$ in the natural state; $d=17.5-18-18.4 \AA$, glycerol-saturated; and $d=9.98-10 \AA$ when heated at $550^{\circ} \mathrm{C}$

2) An intensely swelling, irregular (M-i), mixed-layer mineral with a few packets of $\mathrm{K}-\mathrm{Fe}$ illite. Usually this is a product of the initial glauconitization of oceanic smectites.

3) A poorly swelling, irregular, mixed-layer illitemontmorillonite mineral (i-M) with a few swelling smectite packets. Parameters are $10 \AA$ for the natural mount; 9.8-9.9 $\AA$, glycerol-saturated; and $9.8 \AA$ after heating at $550^{\circ} \mathrm{C}$ (Drits and Sakharov, 1976). This mineral is frequently regarded as a poorly swelling illite, but more precise examination shows that it belongs to the mixedlayer group.

4) A series of mixed-layer irregular (M-i) minerals with variable ratios between the packets, from $100 \mathrm{M}$ up to $100 \mathrm{i}$, or from (M-i) up to (i-M). This series of mixedlayer minerals is defined by asymmetric diffraction peaks: $14.2-14.7 \AA$ in the air-dry state; $18-18.4 \AA$, glycerol-saturated; and $9.98-10 \AA$ after heating at $550^{\circ} \mathrm{C}$.

$\mathrm{The} \mathrm{Mg}, \mathrm{Fe}$-chlorite form of the trioctahedral series is frequently found as a small admixture, sometimes "defective" in structure; $d=13.1-13.8 \AA$ after heating at $550^{\circ} \mathrm{C}$. Often this mineral disintegrated under the same temperature (Drits and Sakharov, 1976).

An admixture of detritic kaolinite $(d=7.14-7.15$ and 3.56-3.57 $\AA$ ) that disappeared after heating was found in Hole 511 in Albian-Coniacian-Santonian sediments. 


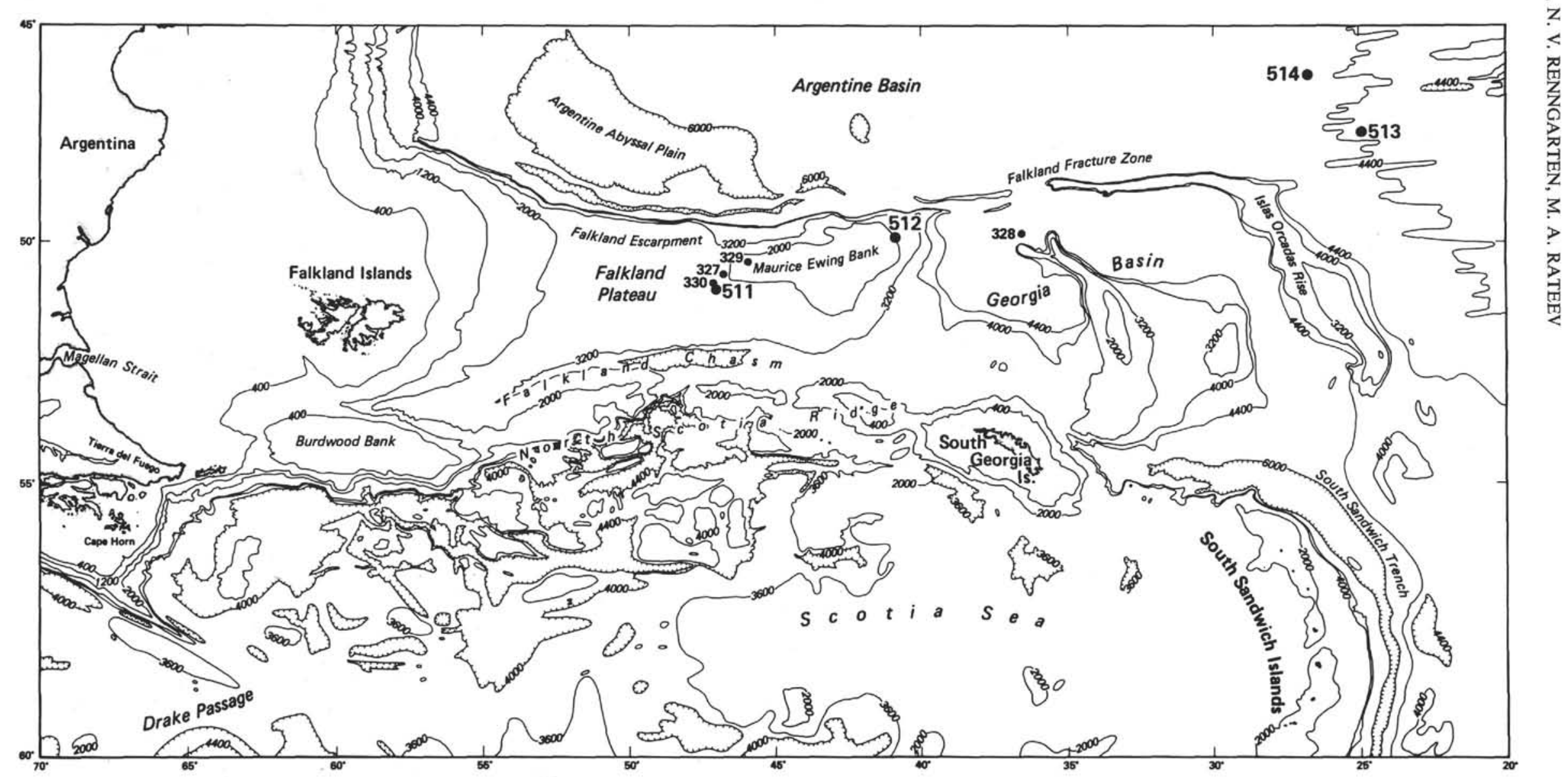

Figure 1. Location of Leg 71 sites. 


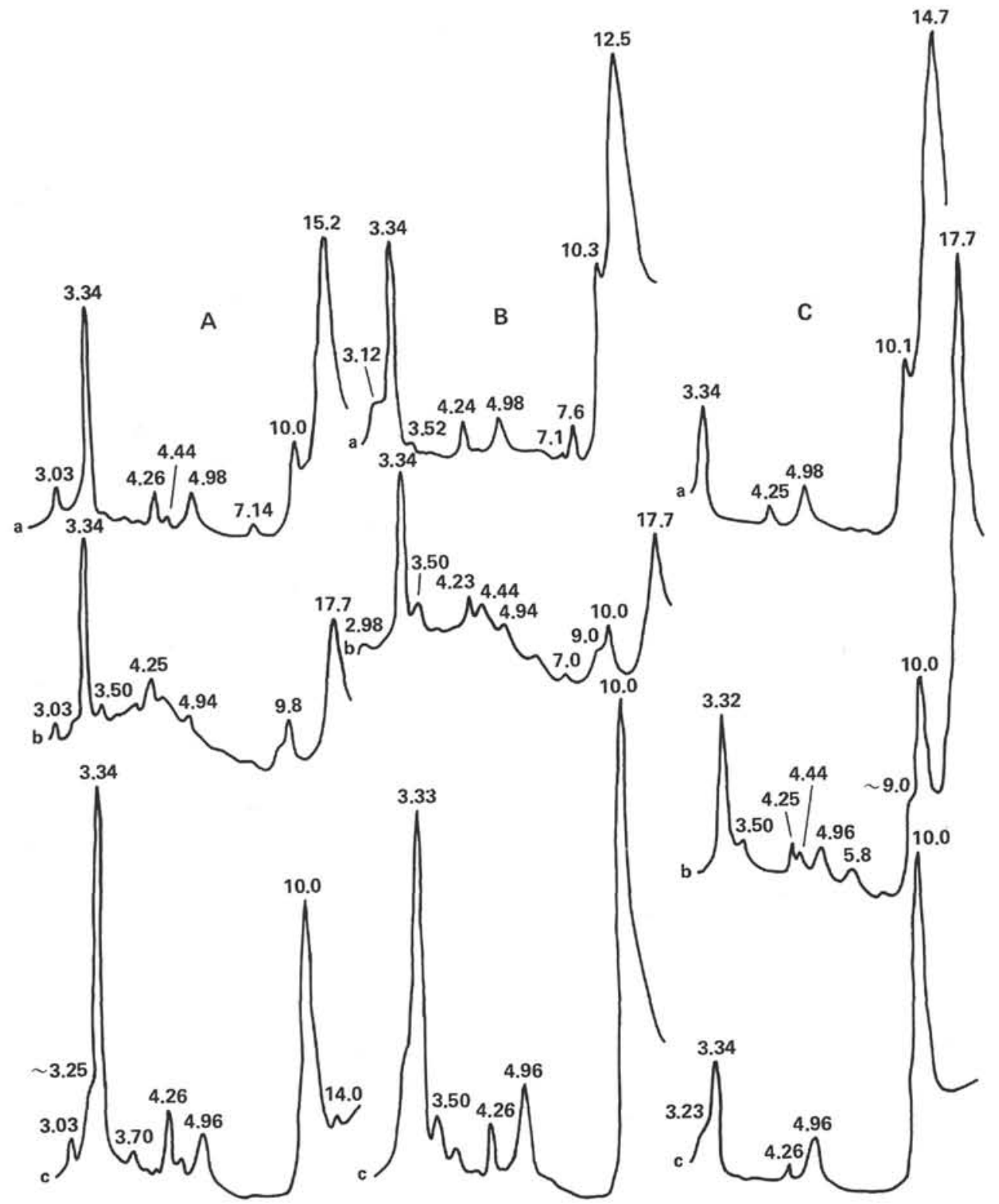

Figure 2. Diffractograms of smectites with different exchange cations, Neocomian-Aptian samples, Hole 511. A. Ca-montmorillonite, Sample 511-60-3, 144-146 cm, coal clays. B. Na-montmorillonite, Sample 511-61-4, 46-50 cm, clays. C. Mg,Ca-montmorillonite, Sample 511-62-4, 166-120 cm, coal clays. (a, natural; b, glycerine saturated; c, heated at $500^{\circ} \mathrm{C}$.)

Beside clay minerals, we also identified small admixtures of zeolite from the heulandite group (with standard parameters), cristobalite, amorphic $\mathrm{SiO}_{2}$ (frequently in combination with poorly crystallized montmorillonite in diatomaceous sediments), quartz, and feldspars.

\section{SEDIMENTATION ENVIRONMENTS IN THE INTERMEDIATE-ZONE BASINS OF THE SOUTH ATLANTIC}

The Leg 71 holes were drilled in a very complex geological region that according to paleomagnetic and biostratigraphic data underwent continental spreading and breakup (South America, Antarctica, and South Africa) during the Mesozoic and Cenozoic (Barker, Dalziel, et al., 1977). These important geological events undoubtedly affected oceanic sedimentation and clay formation in the surface zone. While considering terrigenous sedimentation in the South Atlantic, therefore, Trimonis (1981) paid attention to the significant role played by the tectonic movement of South America and South Africa in supplying terrigenous material to the basins of, the intermediate zone between the continents and ocean, with sharp variations of depth and underwater relief, and variable surface and bottom currents. This is also true of the Falkland Plateau region (Hole 511), which was close to a continental margin of this type: Hole 330 (10 km from Hole 511) encountered granite basement in the form of Precambrian pegmatitic gneisses (found at a depth of $550 \mathrm{~m}$, with an absolute age of $535 \mathrm{~m}$.y.). The intermediate-zone basins (Falkland Plateau, Argentine Basin, etc.) were intensely supplied with terrigenous material during the Albian-Cenomanian. This supply con- 


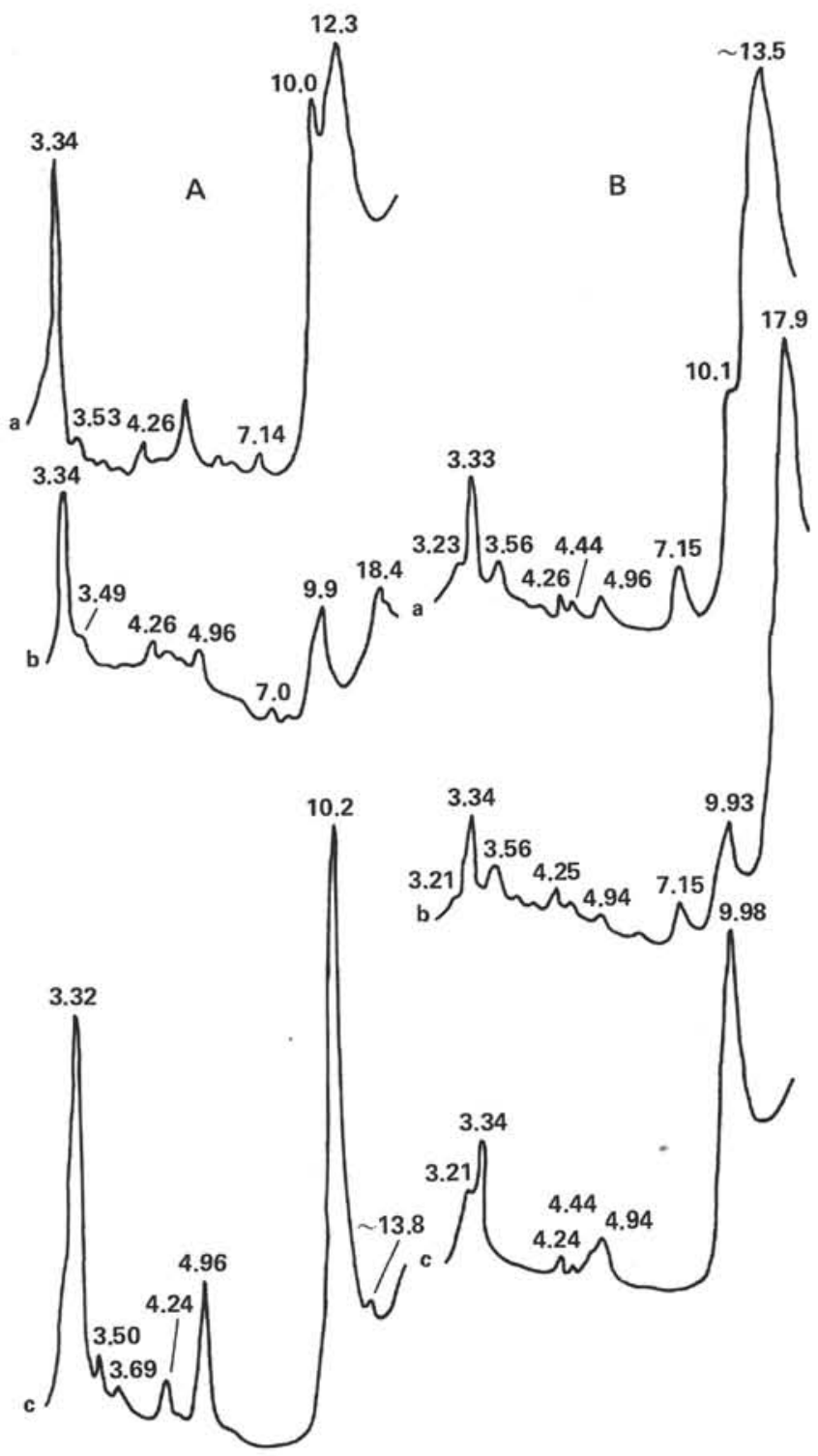

Figure 3. Diffractogram of Hole 511 samples. A. Weakly swelling mixed-layer (i-M) mineral (Drits and Sakharov, 1976), Sample $511-69-2,38-40 \mathrm{~cm}$, Upper Jurassic coal clays (with admixture of illite, chlorite, and quartz). B. Sample $511-46-1,38-40 \mathrm{~cm}$, mixedlayer mineral (M-i) with admixture of illite and kaolinite from upper Santonian clay rocks. (a, natural; b, glycerine-saturated; c, heated at $500^{\circ} \mathrm{C}$.)

siderably decreased at the Cretaceous/Tertiary boundary.

Krasheninnikov and Basov (1981) think that the area of the Falkland Plateau during the Late Jurassic and Early Cretaceous was occupied by shallow, closed basins with limited water circulation, reducing conditions of sedimentation, and the accumulation of black shales with an increased content of organic carbon. At the Early/Late Cretaceous boundary, the gradual subsidence of the basins was replaced by sharp subsidence. Clay limestones and nannocarbonate sediments accumulated in the Albian-Cenomanian. During the Campanian and middle Maestrichtian, the Falkland Plateau area was filled with carbonate foraminiferal oozes with glaucon- ite and zeolites. During the Cenozoic-more precisely, the Paleocene-Eocene-this basin accumulated pelagic clay sediments. After the opening of the Drake Passage, during the Oligocene, the Plateau was mantled by diatom ooze, alternating with coccolith-rich sediments during the period of Antarctic glaciation. Within the Argentine Basin (Holes 513 and 513A), the Neogene-Quaternary sequence consists (from the lower Oligocene up to and including the Pleistocene) of alternations between diatomaceous sediments and nannofossil oozes, reflecting complex fluctuations of the Polar Front of the Antarctic convergence (Krasheninnikov and Basov, 1981).

Such conditions of sedimentation in the area of the holes drilled during Leg 71 to an extent determined both the formation of the lithologic facies and the specific composition of their clay minerals. Evolution of facies conditions during the formation of biogenic-terrigenous (clay) sediments was complicated by numerous hiatuses in sedimentation during the Turonian-early Cenomanian, Paleocene-Maestrichtian, Pliocene-early Oligocene and Pleistocene-Pliocene.

\section{LITHOLOGIC AND FACIES DESCRIPTION OF CLAY MINERAL SEQUENCES}

\section{Hole 511 (Falkland Plateau)}

Hole $511\left(51^{\circ} 00.28^{\prime} \mathrm{S} ; 46^{\circ} 58.30^{\prime} \mathrm{W}\right)$ was drilled and continuously cored to 632 meters in the area of the Falkland Plateau, $10 \mathrm{~km}$ south of Hole 330, DSDP Leg 36. Hole 511 penetrated a broad spectrum of sediments ranging from the Upper Jurassic to the early Oligocene. The thickest part of the sequence is composed of Mesozoic deposits. The stratigraphic column is incomplete: some horizons are either absent or reduced in thickness. All rocks in the sequence were formed from clay or limestone-clay (nannofossil and foraminiferal) oozes, enriched in sapropelic and humic matter, shell detritus, and biogenic $\mathrm{SiO}_{2}$. The rocks contain a slight admixture of silt and fine sand particles. Interlayers with higher admixtures of pyroclastic materials are rare. There were traces of bioturbation at some points.

The lithological features of Hole 511 are subdivided into 7 series, described from the bottom up here.

1) Series VII (Cores 67-70, about $36 \mathrm{~m}$ thick): dark gray fine-foliated Upper Jurassic organic-carbon-rich clays (organic carbon up to $4.1 \%$ ). The rocks are weakly carbonate (up to $7.0 \% \mathrm{CaCO}_{3}$ ). The groundmass of the sediments consists of clay matter saturated by sapropelic and humic colloids, containing plant detritus in the form of wood remains and scattered silt particles of quartz, feldspar, and mica. Heavy minerals are represented predominantly by ore grains and a few grains of zircon, garnet, and rutile. Some vegetable remains are pyritized. The organic remains include large, rounded, yellow algae spore bodies $(d=0.10 \mathrm{~mm})$. The clay particles have a subparallel orientation, occur in a detritic matrix, and do not manifest any postsedimentary alterations. They are mainly represented by weakly swelling mixed-layer illitic-montmorillonite (i-M) minerals (close to hydromica) with an admixture of illite and chlorite. 


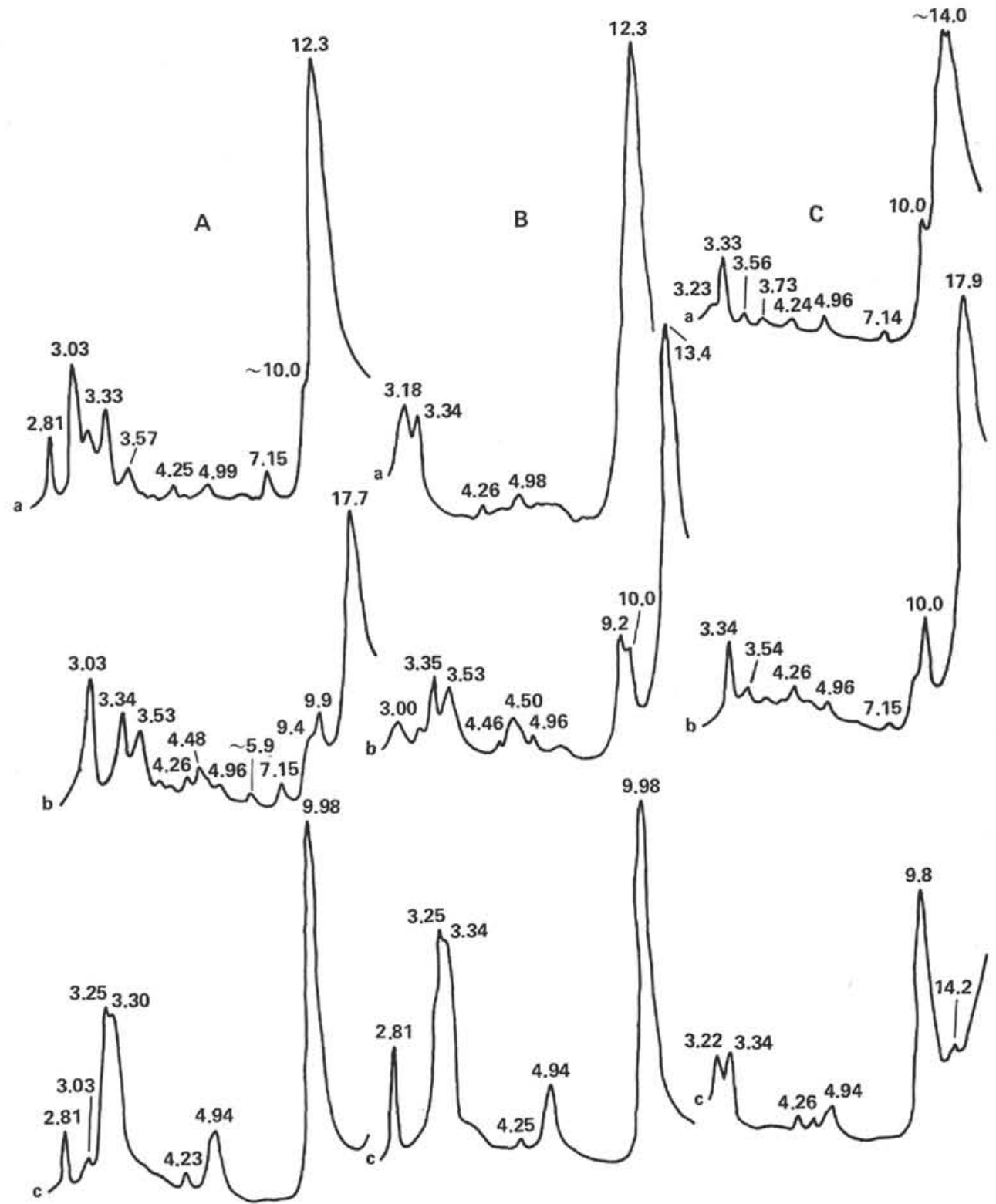

Figure 4. Diffractograms of intensely swelling, disordered, mixed-layer (M-i) minerals (with variable ratios between packets) from foraminiferal Mesozoic oozes, Hole 511. A. Sample 511-50-4, 38-40, Albian. B. Sample 511-27-2, 71-75 cm Campanian age. C. Sample 511-49-6, 36-38 cm, Albian-Cenomanian age. (a, natural; b, glycerine-saturated; $c$, heated at $500^{\circ} \mathrm{C}$.)

The rocks frequently contain rosettelike aggregates of authigenic fine-fibrous gypsum.

2) Series VI (Cores 57-66, about $90 \mathrm{~m}$ thick): Barremian-Aptian-Albian, dark gray clays, coaly, finely foliated, or compact. All of them readily take up water and differ from the underlying series by a slightly higher $\mathrm{CaCO}_{3}(16 \%$, at the expense of coccoliths). The rocks have a microspotted appearance: the light spots are accumulations of coccoliths and the dark ones are colloidal masses of organic carbon with some semidissolved coccoliths. They bear small admixtures of silt particles, charred wood remains, and a few fine fish bones and pockets of authigenous gypsum. The clay matter in the rocks of Series VI is finely dispersed and was possibly formed from the colloid solutions introduced into sedi- ments, together with organic colloids, during later recrystallization in situ into $\mathrm{Ca}, \mathrm{Na}$-smectites, or related intensely swelling (M-i) minerals.

The upper part of this series is composed of lighter rocks without foliation and smaller contents of coarse humus. Here we found very specific minerals (e.g., a sample from Section 511-59-2): pale green, newly formed montmorillonite in the form of isometric and ellipsoidal, distinct, fine-grained particles, probably coprolites. The groundmass consists of clay matter, saturated with humus, with a few remains of charred wood (pyritized in places), foraminiferal shells, and semidissolved coccoliths.

3) Series V (Cores 49-56, about $72 \mathrm{~m}$ thick): Series VI sediments are unconformably overlain by a quite dif- 
ferent series of Albian to Cenomanian sediments that differ even in their light color, with pink-brown tints. These sediments frequently contain large fragments of mollusk shells, foraminifers, and single valves of ostracodes. In some interlayers, the detritic shells are so abundant that the rock can be called a coquina, or organoclastic limestone. The groundmass, enclosing shell fragments, consists of poorly preserved coccoliths and clay matter, irregularly colored by ferruginous pigment in pink and various brown tints.

The clay matter is finely dispersed and under the microscope does not show any postsedimentary transformations. It is composed of two types of mixed-layer minerals (M-i and $\mathrm{i}-\mathrm{M})$, with admixtures of illite and kaolinite.

4) Series IV (Cores 27-48, about 180-200 m thick): Turonian-early Maestrichtian dark gray clays (claystonelike; not completely soaked in water) show fine horizontal laminations, traces of cleavage, and slickensides. By their granulometric composition the clays are almost pure, almost without admixture of silt particles. The carbonate content ranges from 9-21\% (rarely up to $31 \%$ ), averaging $13-15 \%$, and is determined by the presence of foraminifers and coccoliths. The gray color of the rocks is due to finely dispersed organic particles. The clay matter composing the groundmass of this series is polymineralic and detritic in nature; its finest laminae usually have the same orientation and determine the layered texture of the sediments. The pelitic fraction is predominantly composed of a stable, intensely swelling, mixed-layer mineral (M-i) with abundant montmorillonite packets (up to $70 \%$ ). It always contains detritic illite and chlorite. Some samples of the clay show distinct traces of bioturbation.

5) Series III (Cores 23-26, about $36 \mathrm{~m}$ thick): Campanian-Maestrichtian sediments distinctly different from the underlying Series IV and represented by flourlike, pale yellow, chalklike, nanno-foraminiferal oozes. The basic clay-coccolith groundmass contains abundant foraminiferal shells and a few single and twin ostracode shells. The insoluble residue $(27-32 \%)$ consists mainly of clay material $(97-100 \%)$. The clay pelitomorphic matter contains an intensely swelling mixed-layer (M-i) mineral with an admixture of zeolites. Separate fragments of acid volcanic glasses occur among silt particles (composing up to $3 \%$ of the sediments).

6) Series II (Cores 21-22): A peculiar, Paleocene-Eocene, 18-meter thick sequence of green gray, weakly carbonate clays. These have a small admixture of brown and colorless volcanic glass and abundant, authigenic, bright green montmorillonite with traces of glauconitization. The latter occurs as isolated oval and irregular aggregates of grains with sharp outlines. Under crossed nicols they show point polarization, reminding one of glauconite grains. The rocks contain authigenic zeolite, identified radiographically in the fraction $<1 \mu \mathrm{m}$ and seen in the slides and immersion mounts. It is possible that the rocks of this series are by origin connected with clay sediments accumulated during an influx of mineralized hydrotherms. Their formation was accompanied by intensive development of montmorillonitic matter (and partial replacement of its interstitial space for K), authi- genic zeolite, and the dissolution of biogenic carbonate in pore waters.

7) Series I (Cores 2-20, about $180 \mathrm{~m}$ thick): late Eocene-Oligocene, diatomaceous, flourlike, light grey calcareous clay rocks. Their carbonate content ranges between 13 and $30 \%$, averaging up to $19 \%$, and is due to semidissolved coccoliths and foraminiferal shells. The insoluble residue consists of biogenic $\mathrm{SiO}_{2}$ and clay minerals with a negligible admixture of silt particles of quartz, mica, and plagioclase. Biogenic silica is composed of diatom remains with a few radiolarian skeletons and siliceous sponge spicules. The detritus of diatomic frustules contains fragments of Ethmodiscus (Core 511-18). Sample 511-2-2, 60-62 cm contains diatomite with radiolarians and abundant, authigenous bright green smectite. Some foraminiferal shells are recolored by green montmorillonite pigment. The admixture of detritic illite and chlorite is very small.

\section{Holes 513 and 513A (Argentine Basin)}

Holes 513 and 513A were drilled on the western slope of the Mid-Atlantic Ridge at a depth of $4373 \mathrm{~m} \mathrm{(47^{ \circ }}$ $\left.34.99^{\prime} \mathrm{N} ; 24^{\circ} 38.40^{\prime} \mathrm{W}\right)$. The hole penetrated a $387-\mathrm{me}-$ ter-thick sequence $(380 \mathrm{~m}$ of sedimentary rocks and $7 \mathrm{~m}$ of basalts).

The sedimentary sequence overlies the eroded surface of a basalt basement and contains in its base fragments of cherts, basalts, and other rocks. The sedimentary mantle is relatively young: the oldest deposits are Oligocene and are overlain by Miocene, Pliocene, and Pleistocene sediments.

The Oligocene-Pliocene sequence is composed of biogenic and clay-biogenic rocks. They contain remains of diatoms, radiolarians, nannoplankton and foraminifers, all with the following peculiarities. Their insoluble residue in $2 \% \mathrm{HCl}$ consists of pelitic material $(90-99 \%)$ $(<10 \mu \mathrm{m})$, with altering constituents of fine biogenic silica and clay particles. Throughout the sequence, some interlayers contain small admixtures (less than 1\%) of transparent, colorless, acid, volcanic glass fragments.

Lithologically, the sedimentary sequence is subdivided into two sharply different series of rocks, each consisting of 2 subseries, and differing from each other mainly by color, composition, the ratios between silicic and carbonate organisms, and the amount of clay in the pelitic fraction. Boundaries between adjacent series are transitional.

1) Series II (Cores 13-34): light, almost white and pink to pale yellow rocks with fine, distinct, horizontal laminations and abundant calcareous microorganisms.

Subseries IIb (Cores 20-33) is composed of white, chalklike rocks, rich in organic carbonate that averages $70 \%$ of the rock (from $54-78 \%$ ), represented mainly by nannoplankton remains. The absolute residue of these rocks (about $30 \%$ ) consists mainly of diatomaceous material (less frequently radiolarian) and, to a lesser degree, of clay material that is polymineralic and contains illite and a mixed-layer phase (M-i with a variable number of unswelling members, up to $\mathrm{i}-\mathrm{M}$ ).

Subseries IIa (Cores 13-19) consists of pink to pale yellow calcareous and silicic diatomaceous rocks. Siliceous organic remains prevail over carbonate remains 
(average $42 \% \mathrm{CaCO}_{3}$ ) and only interlayers contain up to $58 \%$ biogenic carbonate, at points where the rocks acquire a chalklike habit.

2) Series I (Cores 1-12): differs from Series II mainly by the grey green color of the sediment. In composition they are clay diatomites with a very low biogenic carbonate content (averaging $12 \% \mathrm{CaCO}_{3}$ ) and abundant clay matter. The latter frequently determines, by the arrangement of its particles, the fine-horizontal texture of the oozes, forming fine interlayers within the diatomic detritus. The clay groundmass of the Series I rocks always contains fine, siltlike grains of quartz.

The major part of the clay component in this series is represented by hydromica; next in importance come montmorillonitic minerals with small amounts of nonswelling illite packets. The clay matter groundmass is detrital. However, these rocks sometimes contain distinct authigenic smectitic minerals. Some skeletal remains of radiolarians are filled by a pale green metacolloidal montmorillonitic mass.

Subseries IB (Cores 4-12) sediments are exactly as described for Series I as a whole.

Subseries Ia (Cores 1-3) sediments persistently contain admixtures of unsorted (gravel-sand-silty), polymictic terrigenous material. The proportion of this admixture is negligible but its persistence is very characteristic. The terrigenous material consists of grains of quartz, feldspar of different metamorphic rocks, and siltstones with serpentinitic cement, among others. The heavy fraction $(0.10-0.01 \mathrm{~mm})$ consists of zircon, garnet, epidote, clinopyroxene, green hornblende, minerals of the anatase and brookite groups, etc. The terrigenous gravel-sand-silty material was undoubtedly introduced into sediments by drift ice.

\section{DISTRIBUTION OF CLAY MINERAL ASSEMBLAGES}

\section{Hole 511}

The distribution of clay minerals in the sequences recovered conforms with the geological history of the region and the evolution of sedimentation conditions (see Table 1).

\section{Series VII (Cores 69-70)}

The clay fraction $(<1 \mu \mathrm{m})$ predominantly consists of micaceous mixed-layer (i-M) minerals with abundant illite packets and a small proportion of swelling smectitic layers. In this, the series distinctly differs from the overlying Upper Jurassic-Barremian-Aptian sediments. Besides micaceous, weakly swelling, detritic mixed-layer (i-M) minerals, the clay fraction contains separate phases of illite and traces of chlorite and quartz.

\section{Series VI (Cores 57-66)}

Clay minerals are represented by montmorillonites with different cations of the exchange complex, e.g., $\mathrm{Na}, \mathrm{Ca}-$ and $\mathrm{Mg}, \mathrm{Ca}-\mathrm{montmorillonites} \mathrm{or} \mathrm{intensely} \mathrm{swell-}$ ing, mixed-layer (M-i) mineral, close to smectite and also with $\mathrm{Na}$ and $\mathrm{Ca}$ in the smectite members. They also show traces of "initial glauconitization" (i.e., the ap- pearance of a $\mathrm{K}, \mathrm{Fe}$-illite member with $d=11 \AA$ in the mixed-layer, $\mathrm{M}$-i minerals) at the stage of early diagenesis (Timofeev et al., 1979), during interaction between rather finely dispersed smectites and colloidal organic matter and dissolved $\mathrm{K}$ of pore waters. The clay fraction of these rocks has a very small detritic admixture with only negligible amount of illite and traces of chlorite and quartz.

\section{Series V (Cores 49-56)}

This clay mineral assemblage contains a number of mixed-layer minerals from (M-i) up to (i-M) with sharp variations in the ratio between structural members, from $100 \mathrm{M}$ up to $100 \mathrm{i}$. It also has a small detritic admixture of illite and kaolinite. The chlorite here is not typical and possibly is derived from a subtropical weathering profile in the source area of the clay material.

\section{Series IV (Cores 27-47)}

The clay fraction is mainly composed of an intensely swelling, mixed-layer $(\mathrm{M}-\mathrm{i})$ mineral with a predominance of montmorillonitic layers (M from 60-90\%). Mica (illite, i) layers in the structure of these mixed-layer minerals ranges from $10-40 \%$, and they have a persistent admixture of illite and chlorite, quartz, and feldspar. A small admixture of kaolinite $(5 \%)$ is traced only in the lower Coniacian-Santonian interval (Cores 5340) of Series IV, and disappears in its upper SantonianCampanian-Maestrichtian part (above Core 40).

\section{Series III (Cores 23-26)}

The major component of the clay assemblage in this series is an intensely swelling, mixed-layered (M-i) mineral with a rather persistent ratio between structural members (M-i about 80:20) accompanied by zeolite from the heulandite group. This assemblage of layered silicates was formed in situ, i.e., authigenically during diagenesis or at the expense of redeposited products of the transformation of volcanics of a uniform composition, possibly close to andesite-basalt.

\section{Series II (Cores 21-22)}

Green gray, low-carbonate clay sediments with an admixture of colorless and brown volcanic glass with abundant authigenic green, weakly glauconitized smectite (in the zeolite assemblage from the heulandite group) were deposited on Maestrichtian rocks after a long hiatus between the Maestrichtian and Paleocene. The rock underwent initial glauconitization of the smectites, manifested in the appearance of a few members of a glauconite-like $\mathrm{K}, \mathrm{Fe}$-hydromica (amounting to $5 \%$ ) in the structure of the smectite. Some influx of hydrothermal solutions was also possible. The admixture of detrital illite and quartz in these sediments is inconsequential.

\section{Series I (Cores 2-20)}

The clay fraction is predominantly composed of smectite. In the lower Eocene-Oligocene part of the sequence (Cores 10-20) smectites are more or less pure, whereas in the upper lower Oligocene they are intensely swelling, mixed-layer (M-i) minerals with a low content of mica- 
Table 1. X-ray diffraction analysis of clay minerals, Hole 511.

\begin{tabular}{|c|c|c|c|c|c|c|c|}
\hline Age & $\begin{array}{l}\text { Core-Section } \\
\text { (interval in } \mathrm{cm} \text { ) }\end{array}$ & Series & Genetic Facies & $\begin{array}{l}\text { Clay Minerals } \\
(10 \mu \mathrm{m} \text { fraction })\end{array}$ & $\begin{array}{l}\text { Clay minerals } \\
\text { assemblage }\end{array}$ & $\begin{array}{l}\text { Macrofacies } \\
\text { (facies zones) }\end{array}$ & Microfacies \\
\hline \multirow[t]{2}{*}{$\begin{array}{l}\text { early } \\
\text { Oligocene }\end{array}$} & $\begin{array}{l}2-4,14-16 \\
3-2,110-112 \\
4-3,40-42 \\
5-3,70-72 \\
6-4,75-77 \\
9-3,89-93 \\
\end{array}$ & Ia 7 & $\begin{array}{l}\text { Diatomite, calc-clayey, with } \\
\text { radiolarians } \\
\text { Diatomite, calc-clayey with fora- } \\
\text { minifers and fish remains }\end{array}$ & $\begin{array}{l}\text { Montmorillonite, illite, quartz, feldspar } \\
\text { Illite, chlorite, quartz } \\
\text { Mixed-layer } \mathrm{M}-\mathrm{i} \text {, illite, chlorite, quartz, } \\
\text { feldspar } \\
\text { Montmorillonite, illite, chlorite, } \\
\text { quartz, feldspar } \\
\text { Mixed-layer } \mathrm{M}-\mathrm{i} \text {, illite, chlorite } \\
\text { (defective), quartz } \\
\text { Mixed-layer } \mathrm{M}-\mathrm{i} \text {, illite, traces of chlo- } \\
\text { rite, quartz, feldspar }\end{array}$ & $\begin{array}{l}\text { Mixed-layer, intensely } \\
\text { swelling } \mathrm{M} \text {-i with } \\
\text { admixtures of } \\
\text { illite and chlorite }\end{array}$ & $\begin{array}{l}\text { Deep sea } \\
\text { pelagic } \\
\text { sediment }\end{array}$ & \multirow[t]{2}{*}{$\begin{array}{l}\text { Deep sea biogenic } \\
\text { silicic sedi- } \\
\text { mentary facies } \\
\text { with slight } \\
\text { smectitization } \\
\text { of volcanic } \\
\text { glasses }\end{array}$} \\
\hline & $\begin{array}{l}11-2,36-40 \\
16-1,60-62\end{array}$ & lb & $\begin{array}{l}\text { Diatomite, calc-clayey with fora- } \\
\text { miniferal tests } \\
\text { Diatomite, calc-clayey with a few } \\
\text { grains of glauconite and } \\
\text { radiolarians }\end{array}$ & $\begin{array}{l}\text { Montmorillonite, illite, chlorite, quartz } \\
\text { Montmorillonite, illite, chlorite } \\
\text { (defective) }\end{array}$ & $\begin{array}{l}\text { Montmorillonite with } \\
\text { admixtures of } \\
\text { illite and chlorite }\end{array}$ & & \\
\hline $\begin{array}{l}\text { Paleocene- } \\
\text { Eocene }\end{array}$ & $\begin{array}{l}17-3,28-30 \\
21-1,10-12(a)\end{array}$ & II & $\begin{array}{l}\text { Diatomite, calc-clayey } \\
\text { Clay, enclosing large authigenic } \\
\text { pods of green glauconite with } \\
\text { fragments of volcanic glasses } \\
\text { and zeolites } \\
\text { Green glauconite }\end{array}$ & $\begin{array}{l}\text { Montmorillowite, illite, chlorite (few), } \\
\text { quartz } \\
\text { Mixed-layer } \mathrm{M} \text {-i with high } \% \text { of illite } \\
\text { layers, illite, heulandite, quartz } \\
\text { Mixed-layer } \mathrm{M} \text { - } \mathrm{i} \text { layers with variable } \\
\text { content of } \mathrm{M} \text { and } \mathrm{i}\end{array}$ & $\begin{array}{l}\text { Glauconitic-montmo- } \\
\text { rillonitic with } \\
\text { zeolite }\end{array}$ & & \multirow[t]{2}{*}{$\begin{array}{l}\text { Facies of initial } \\
\text { glauconitization } \\
\text { after acid-vol- } \\
\text { caniclastic }\end{array}$} \\
\hline $\begin{array}{l}\text { Campanian- } \\
\text { Maestrich- } \\
\text { tian }\end{array}$ & $\begin{array}{l}24-2,46-48 \\
25-1,78-82\end{array}$ & III & $\begin{array}{l}\text { Nanno-foraminiferal ooze with } \\
\text { ostracode remains } \\
\text { Clay with a few radiolarian } \\
\text { remains }\end{array}$ & $\begin{array}{l}\text { Mixed-layer M-i, illite, admixture of } \\
\text { chlorite, quartz, feldspar } \\
\text { Mixed-layer } M-i \text { with } M: i \quad 75: 25 \text {, illite, } \\
\text { zeolite from heulandite group, } \\
\text { quartz }\end{array}$ & $\begin{array}{l}\text { Mixed-layer M-i with } \\
\text { zeolite (after acid } \\
\text { volcaniclastics) }\end{array}$ & & \\
\hline Campanian & $\begin{array}{l}27-2,71-75 \\
28-5,92-96 \\
30-3,50-52 \\
31-3,66-68 \\
33-4,72-74 \\
35-2,52-54 \\
36-4,22-24\end{array}$ & IV & $\begin{array}{l}\text { - Homogeneous clay } \\
\text { Homogeneous clay (cleaved) } \\
\text { Homogeneous clay with forami- } \\
\text { niferal remains }\end{array}$ & 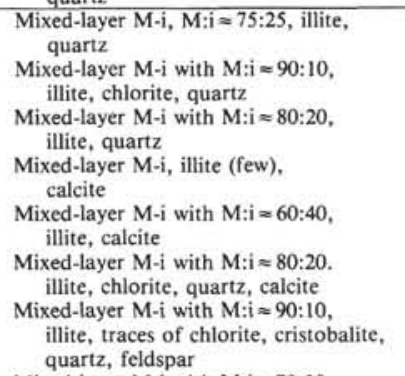 & $\begin{array}{l}\text { Mixed-layer M-i with } \\
\text { admixtures of } \\
\text { illite and chlorite }\end{array}$ & $\begin{array}{l}\text { Relatively shal- } \\
\text { low sea ba- } \\
\text { sins of the } \\
\text { transitional } \\
\text { zone }\end{array}$ & $\begin{array}{l}\text { Terrigenous clayey, } \\
\text { slightly carbon- } \\
\text { ate facies, rela- } \\
\text { tively cold } \\
\text { climate }\end{array}$ \\
\hline $\begin{array}{l}\text { Turonian- } \\
\text { Santonian }\end{array}$ & $\begin{array}{l}39-3,39-43 \\
40-4,40-44 \\
46-1,38-40 \\
47-6,48-50\end{array}$ & & $\begin{array}{l}\text { Homogeneous clay with forami- } \\
\text { niferal remains } \\
\text { Clay, pyritized in places, with } \\
\text { small foraminiferal shells } \\
\text { Homogeneous clay, slightly silty } \\
\text { Homogeneous clay, with small } \\
\text { foraminiferal tests and large } \\
\text { remains of fish bones and } \\
\text { single coccoliths }\end{array}$ & $\begin{array}{l}\text { Mixed-layer M-i with } M: i \approx 70: 30, \\
\text { illite, kaolinite, chlorite (defective), } \\
\text { quartz } \\
\text { Montmorillonite, illite, chlorite, traces } \\
\text { of kaolinite, quartz, feldspar } \\
\text { Mixed-layer M-i, illite, kaolinite, } \\
\text { feldspar } \\
\text { Mixed-layer M-i with } M: i \approx 70: 30, \\
\text { illite, chlorite, kaolinite, traces of } \\
\text { quartz, feldspar }\end{array}$ & $\begin{array}{l}\text { Mixed-layer } \mathrm{M} \text {-i with } \\
\text { illite, chlorite, and } \\
\text { an admixture of } \\
\text { kaolinites }\end{array}$ & & \\
\hline $\begin{array}{c}\text { early- } \\
\text { middle } \\
\text { Albian to } \\
\text { Cenomanian }\end{array}$ & $\begin{array}{l}50-4,38-40(a) \\
50-4,38-40(b) \\
51-6,62-66 \\
53-4,76-80(a) \\
53-4,76-80(b) \\
55-5,38-40\end{array}$ & V & $\begin{array}{l}\text { Red nanno-foraminiferal ooze } \\
\text { with large fragments of } \\
\text { mollusks }\end{array}$ & $\begin{array}{l}\text { Mixed-layer M-i, illite, chlorite, quartz } \\
\text { Mixed-layer M-i, illite, kaolinite, cal- } \\
\text { cite quartz } \\
\text { Mixed-layer M-i, illite, kaolinite, } \\
\text { quartz } \\
\text { Mixed-layer minerals } \mathrm{M} \text {-i, illite, kao- } \\
\text { linite, quartz } \\
\text { Mixed-layer } \mathrm{M} \text {-i (from } 100 \mathrm{M} \text { up to } \\
100 \mathrm{i} \text { ), illite, kaolinite (small admix- } \\
\text { ture), chlorite, quartz, feldspar } \\
\text { Mixed-layer M-i (from } 100 \mathrm{M} \text { up to } \\
100 \mathrm{i} \text { ), admixtures of kaolinite and } \\
\text { quartz } \\
\mathrm{Mg}, \text { Ca-montmorillonite, illite (few), } \\
\text { quartz }\end{array}$ & $\begin{array}{l}\text { Mixed-layer } \mathrm{M}-\mathrm{i} \text { up } \\
\text { to } \mathrm{i}-\mathrm{M} \text { (with vari- } \\
\text { able packets from } \\
100 \mathrm{M} \text { to } 100 \mathrm{i} \text {, } \\
\text { admixtures of illite } \\
\text { and kaolinite }\end{array}$ & & $\begin{array}{l}\text { Clay-biogenic } \\
\text { nanno-forami- } \\
\text { niferal carbon- } \\
\text { ate facies with } \\
\text { kaolinite prod- } \\
\text { ucts washed } \\
\text { out of crusts of } \\
\text { weathering }\end{array}$ \\
\hline $\begin{array}{l}\text { Late } \\
\text { Jurassic- } \\
\text { Barremian- } \\
\text { Aptian- } \\
\text { Albian }\end{array}$ & $\begin{array}{l}59-2,9-11 \\
60-3,144-146 \\
61-4,46-50 \\
62-4,116-120 \\
64-3,26-30 \\
\end{array}$ & VI & $\begin{array}{l}\text { Nanno ooze with newly formed } \\
\text { glauconite-like mineral and } \\
\text { gypsum rosettes } \\
\text { Nanno ooze, coaly with spots of } \\
\text { green clay } \\
\text { Nanno ooze, coaly with gypsum } \\
\text { Nanno ooze, coaly, silty, with } \\
\text { gypsum }\end{array}$ & $\begin{array}{l}\text { Mixed-layered minerals M-i, illite, } \\
\text { quartz } \\
\text { Ca-montmorillonite, illite, chlorite, } \\
\text { quartz, calcite } \\
\text { Na-montmorillonite, illite, gypsum, } \\
\text { admixtures of chlorite and quartz } \\
\mathrm{Mg}, \mathrm{Ca} \text {-montmorillonite, illite, quartz } \\
\text { Mixed-layer M-i, illite, } 7 \mathrm{~A} \text { mineral, } \\
\text { quartz }\end{array}$ & $\begin{array}{l}\text { Montmorillonitic } \\
\text { mixed-layer } \mathrm{M}-\mathrm{i} \\
\text { with admixture of } \\
\text { illite and chlorite }\end{array}$ & & $\begin{array}{l}\text { Terrigenous facies } \\
\text { with abundant } \\
\text { organic matter, } \\
\text { warm and hu- } \\
\text { mid climate }\end{array}$ \\
\hline $\begin{array}{c}\text { Late } \\
\text { Jurassic }\end{array}$ & $69-2,38-40$ & VII & $\begin{array}{l}\text { Silty clay with spots of organic } \\
\text { matter }\end{array}$ & $\begin{array}{l}\text { Mixed-layer M-i with small } \% \text { of } \\
\text { M-layers, illite, chlorite (traces) }\end{array}$ & $\begin{array}{l}\text { Micaceous weakly } \\
\text { swelling i-M } \\
\text { mixed-layer min- } \\
\text { eral with admix- } \\
\text { tures of illite and } \\
\text { chlorite }\end{array}$ & & \\
\hline
\end{tabular}


ceous illite packets (not more than 15\%). The major part of the clay smectite fraction throughout the upper Eocene to lower Oligocene sequence contains a considerable admixture of detrital minerals: illite, chlorite, quartz, and feldspar. In deep sea conditions (in the area of the Falkland Plateau during the late Eocene to early Oligocene) where diatomic sediments, enriched in authigenous silica, and close to the Polar Front, were accumulating, the smectites can be formed partially diagenetically after the available volcaniclastic material or can be transported by currents from very remote areas because of their finely dispersed state. The obvious authigenic replacement of radiolarian skeletons by green ferruginous smectite which also coats the shells of foraminifers was noted in Sample 511-2-2, 60-62 at the boundary between lower Oligocene diatomites and Quaternary gravel-sandy nannoplanktonic oozes. Thus, the clay fraction of the Mesozoic sequence in the area of the Falkland Plateau, Hole 511 (except of the lowermost part, Cores 69-70) is predominantly composed either of minerals from the smectite group, or montmorillonites or related intensely swelling mixed-layer minerals from the $\mathrm{M}$-i series. Illitic micaceous and chloritic minerals are a minor admixture (about $5-15 \%$ ) whereas, in the sequence from Holes 513 and 513A within the Argentine Basin, micaceous illitic materials are the main components of the Oligocene-Miocene-Pliocene interval and smectites are everywhere minor.

\section{Holes 513 and 513A}

The nannofossil carbonate deposits in this area (Core 513A-33) contain remains of diatoms and foraminiferal tests and overlie basalts. They are composed of illite, montmorillonite with cristobalite, and abundant amorphic $\mathrm{SiO}_{2}$. Montmorillonite is developed after basalt fragments (see Table 2).

\section{Series II (Cores 513A-13-34)}

The clay fraction is composed of illite and a number of mixed-layer minerals with a variable ratio between members, from M-i up to i-M. Chlorite and less frequently cristobalite admixtures are insignificant. This series of mixed-layer minerals was possibly formed by the disintegration of trioctahedral micas from biotitic series. Series II has a persistent assemblage of clay minerals that makes it difficult to subdivide into subseries. Series II is early late Oligocene in age.

\section{Series I (Cores 1-12)}

This series of diatomic clay oozes, is subdivided into two subseries according to the composition of its clay fraction and its lithology.

Subseries Ib (Cores 513-8-12; Middle to late Miocene) is represented by diatomaceous clay oozes with a clay fraction composed of illite and an intensely swelling mixed-layer $(\mathrm{M}-\mathrm{i})$ mineral with small admixtures of chlorite.

Subseries Ia (Cores 1-7; Pliocene) is represented by diatomic clay-silty and sand oozes with a clay fraction containing, beside illite, montmorillonite with abundant amorphic $\mathrm{SiO}_{2}$ and small admixtures of chlorite.

\section{HISTORY OF MESOZOIC-CENOZOIC SEDIMENTATION}

\section{The Falkland Plateau, Hole 511}

The specific features in the evolution of facies environments during sediment accumulation within the Falkland Plateau can be subdivided into two successive stages.

The general trend in the evolution of sedimentary processes was a gradual replacement of marine shallowwater by deep-water oceanic environments.

The first stage of sedimentation took place in the shallow-water basins of the transitional zone (Table 1, macrofacies 2). It comprised the Mesozoic sedimentation period from the late Jurassic up to the early Maestrichtian (Cores 26-70). This stage is characterized by four series of rocks, which correspond genetically to four types of sedimentary facies. Two lower series (VIVIII) include rocks formed from shallow-water sediments (possibly near shore), represented mainly by terrigenous clay oozes with biogenic carbon (coal particles, sapropelic and humic colloids). Where the aeration of natural and pore waters was sufficient, the abundant organic remains in the oozes favored the dissolution of skeletal remains and calcitic shells. The presence of authigenic gypsum in the sediments shows that part of water basin underwent periodic changes in the salinity of sea water.

While Series VI and VII accumulated, the climate of the nearby land was possibly humid and moderately warm; thus Series VII (Upper Jurassic) accumulated in moderate climatic conditions, and the sedimentation basin was filled mainly with detrital clay and organic material.

Fine clay material was delivered into relatively closed sea basins from nearby areas of outwashing. It consisted of heterogeneous products of reworking not only of shallow-water marine, but positively subaerial continental facies in a warm marine climate, at least during the early Mesozoic (Barker, Dalziel, et al., 1977).

As deposition of the leaflike clays or so-called "black shales" with detritic humic organic matter began, the Late Jurassic basin was filled predominantly by a micaceous (illitic), weakly swelling mixed-layer (i-M) mineral, delivered from the adjacent water basins in a form of detritic tabular particles in medium and coarse-pelitic dimensions, possibly together with a few unswelling, perhaps muscovitic micas and chlorite. This detritic complex was formed without considerable interaction with organic matter (also detritic).

During the accumulation of the sediments of Series VI, the climate possibly became warmer. Organic matter favored the process of authigenous smectitization with the formation of organo-montmorillonitic complexes which, depending on the variation of cations in the pore waters, were diagenetically transformed into varieties of $\mathrm{Ca}, \mathrm{Mg}$, and $\mathrm{Ca}$ - or Na-montmorillonite. The admixture of detritic illites here was relatively small. At the end of the period the climate became drier.

During the transgressive phase of the development of this area, the shallow-water facies conditions of sedi- 
Table 2. Clay mineral assemblages, Holes 513 and 513A.

\begin{tabular}{|c|c|c|c|c|c|c|c|}
\hline Age & $\begin{array}{c}\text { Sample } \\
\text { (interval in } \mathrm{cm} \text { ) }\end{array}$ & Series & Genetic facies & $\begin{array}{l}\text { Clay Minerals } \\
(10 \mu \mathrm{m} \text { fraction })\end{array}$ & $\begin{array}{l}\text { Clay mineral } \\
\text { assemblages }\end{array}$ & $\begin{array}{l}\text { Macrofacies } \\
\text { (facies zone) }\end{array}$ & Microfacies \\
\hline Pliocene & $\begin{array}{l}513-6-4,44-46 \\
513 A-4-4,85-87\end{array}$ & Ia & $\begin{array}{l}\text { Diatomaceous mud, clayey-silty } \\
\begin{array}{l}\text { Diatomaceous ooze, clayey with admixtures } \\
\text { of silty and sandy material }\end{array} \\
\text { Diatomaceous ooze, clayey with radiolarians }\end{array}$ & $\begin{array}{l}\text { Illite (i), montmorillonite (dispersed, } \\
\text { badly crystallized), trace chlorite, } \\
\text { much amorphous } \mathrm{SiO}_{2} \text {, feldspar, } \\
\text { quartz } \\
\text { Illite, montmorillonite (poorly crys- } \\
\text { tallized), traces of chlorite, abun- } \\
\text { dant amorphous } \mathrm{SiO}_{2} \text {, feldspar, } \\
\text { quartz } \\
\text { Illite, montmorillonite (poorly crys- } \\
\text { tallized), amorphous } \mathrm{SiO}_{2} \text {, feld- } \\
\text { spar, quartz }\end{array}$ & $\begin{array}{l}\text { Illitic-montmorillonitic } \\
\text { (with admixtures of } \\
\text { chlorite and amor- } \\
\text { phic } \mathrm{SiO}_{2} \text { ) }\end{array}$ & $\begin{array}{l}\text { Deep sea pelagic } \\
\text { sediments }\end{array}$ & $\begin{array}{l}\text { Clay-silicate deep sea } \\
\text { sedimentary facies } \\
\text { with glacio-terrig- } \\
\text { enous material } \\
\text { transported by } \\
\text { drift ice }\end{array}$ \\
\hline $\begin{array}{l}\text { middle- } \\
\text { late } \\
\text { Miocene }\end{array}$ & $\begin{array}{l}513 \mathrm{~A}-8-4,129-131 \\
513 \mathrm{~A}-10-5,110-112 \\
513 \mathrm{~A}-12-4,70-72\end{array}$ & Ib & $\begin{array}{l}\text { Diatomaceous ooze, clayey } \\
\text { Diatomaceous ooze, clayey with radiolarians }\end{array}$ & $\begin{array}{l}\text { Illite, mixed-layer M-i minerals, } \\
\text { small admixture of chlorite, } \\
\text { feldspar, quartz } \\
\text { Illite, mixed-layer M-i minerals, } \\
\text { chlorite (defective), feldspar, } \\
\text { quartz }\end{array}$ & $\begin{array}{l}\text { Illitic-mixed-layer } \\
\text { minerals } \mathrm{M}-\mathrm{i} \text {, with } \\
\text { admixtures of } \\
\text { chlorites }\end{array}$ & & \\
\hline Oligocene & $\begin{array}{l}513 A-16-2,93-95 \\
513 A-17-1,74-76 \\
513 A-17-3,74-76 \\
513 A-18-2,22-24 \\
513 A-20-2,26-28 \\
513 A-24-2,46-48 \\
513 A-28-2,96-98 \\
513 A-29-2,124-126 \\
513 A-30-4,62-64 \\
513 A-33-5,50-52\end{array}$ & II] & $\begin{array}{l}\text { Nannochalk with fragments of diatoms } \\
\text { Nanno-ooze with fragments of diatoms and } \\
\text { radiolarians } \\
\text { Nannochalk with fragments of diatoms and } \\
\text { radiolarians } \\
\text { Nannochalk with fragments of diatoms, ra- } \\
\text { diolarians and foraminiferal tests } \\
\text { Nannochalk with biogenic } \mathrm{SiO}_{2} \text { and frag- } \\
\text { ments of foraminifers }\end{array}$ & $\begin{array}{l}\text { Illite, mixed-layer M-i up to i-M, } \\
\text { chlorite, quartz, feldspar } \\
\text { Illite, series of mixed-layer minerals } \\
\text { from M-i up to i-M, chlorite, } \\
\text { cristobalite, feldspar, quartz } \\
\text { Illite, mixed-layer, from M-i up to } \\
\text { i-M, chlorite (defective), cristo- } \\
\text { balite, feldspar, quartz } \\
\text { Illite, mixed-layer series } \mathrm{M} \text {-i up to } \\
\text { i-M, cristobalite, quartz, feldspar } \\
\text { Illite, mixed-layer M-i, chlorite } \\
\text { (few), feldspar, quartz } \\
\text { - Illite, mixed-layer from M-i up to } \\
\text { i-M, chlorite (defective, quartz } \\
\text { feldspar } \\
\text { Illite, mixed-layer from } \mathrm{M}-\mathrm{i} \text { up to } \\
\text { i-M, chlorite (defective), cristo- } \\
\text { balite, quartz, feldspar } \\
\text { Illite, montmorillonite, cristobalite, } \\
\text { abundant amorphic } \mathrm{SiO}_{2} \text {, } \\
\text { quartz, feldspar }\end{array}$ & $\begin{array}{l}\text { Illite with series of } \\
\text { mixed-layer miner- } \\
\text { als from } M-\mathrm{i} \text { up to } \\
\mathrm{i}-\mathrm{M} \text { with admix- } \\
\text { tures of chlorite, } \\
\text { sometimes with } \\
\text { cristobalite } \\
\text { Illite with mixed-layer } \\
\text { minerals from } \mathrm{M}-\mathrm{i} \\
\text { up to } \mathrm{i}-\mathrm{M} \text {, admix- } \\
\text { tures of chlorite, } \\
\text { sometimes with } \\
\text { cristobalite }\end{array}$ & & $\begin{array}{l}\text { Deep sea silicic- } \\
\text { carbonate sedi- } \\
\text { mentary facies de- } \\
\text { posited in envi- } \\
\text { ronments, rela- } \\
\text { tively warm } \\
\text { climate }\end{array}$ \\
\hline
\end{tabular}

inentation were replaced by deeper sea conditions, and Series V deposits began to accumulate. During this period, the basin accumulated clay-biogenic brown oozes, almost without an admixture of vegetative organic remains. The clay-coccolithic groundmass of sediments contained variable amounts of foraminiferal shells, fragments of mollusk shells, etc. These "red brown" lowermiddle Albian to Cenomanian sediments (Series V) have peculiarly diversified and heterogeneous clay minerals with a predominance of mixed-layer clays, from near smectites (M-i) up to near micas (i-M) and illites. Such a range in the ratio between smectitic and illitic members (from $100 \mathrm{M}$ up to $100 \mathrm{i}$ ) could hardly occur in the relatively monotonous physico-chemical medium of a sea basin or its sediments. Usually they are formed during the degradation of micas in an environment of subaerial weathering and warm climate. The continental source area for these sediments also provided kaolinite and $\mathrm{Fe}$ hydroxides. These clay minerals of continental or nearshore marine faces were most likely delivered by the redeposition of Jurassic ferro-kaolinitic clays of warm climates (recovered by Hole 330, DSDP Leg 36) during the erosion of nearby lands which remained uplifted.

The washing of kaolinite down from the continent (at the expense of redeposition of more ancient kaolinitebearing rocks) is registered in the first half of the formation of Series IV, up to the end of the middle Santonian (up to Core 39).

Sediments of Series V with a sharp contact and sedimentation hiatus are overlain by a rather thick series (about $200 \mathrm{~m}$ ) of green gray clay sediments of Series IV, formed under a relatively calm tectonic regime, in which material accumulated under conditions of long, compensated down-warping. The sedimentary material was predominantly terrigenous and was eroded from the land in the form of suspended detritic clay. The mineralogical composition of the clay fraction of these sediments is represented predominantly by stable, intensely swelling mixed-layer minerals (M-i) close to smectite, with admixtures of detritic minerals (hydromicas and chlorites). Slow sedimentation promoted the oxidation of the oozes and therefore the intense decomposition of vegetative remains and the increased partial pressure of $\mathrm{CO}_{2}$ in the oozes. As a result, the oozes became weakly carbonate, at the expense of biogenic Ca. Erosion of predominantly clay material from the land could take place in conditions of moderate, humid, and rather cool climate. At this time the continent was possibly subjected to the effect of cold Antarctic sea currents. This would cause the retreat to the north of warm surface waters together with thermophilic forms of fauna and flora.

The second stage of sedimentation was characterized by the accumulation of deep-water, pelagic sediments (see Table 1 \#1). It encompassed the middle Maestrichtian up to the Pleistocene (at Hole 511 the top of the section contains early Oligocene rocks). The formation of the deposits was rather complex and accompanied by active tectonic movements, resulting in frequent sedimentary hiatuses and volcanic activity.

This oceanic stage includes three distinct facies or microfacies of deep sea pelagic sedimentation accompanied 
by the accumulation of the three corresponding upper series of the sequence.

Sharp shifts of the pelagic facies took place during the formation of the Campanian and Maestrichtian Series III because the study area subsided, resulting in the formation of intensely swelling, clay-biogenic, deep sea, nanno-foraminiferal, oozes (with $\mathrm{CaCO}_{3}$ content up to $67 \%$ ) in the areas that previously accumulated Mesozoic clays. The appearance of volcaniclastics in these oozes gave rise to an intensive development of authigenous sedimentation in the form of intensely swelling, mixedlayer (M-i) minerals accompanied by the formation of heulandite. The detritic admixture of illite and chlorite is insignificant.

The sediments of Series II (Paleocene-Eocene) were deposited in rather peculiar environments. Ashfalls during this period were the major source of sedimentary material. The green oozes were enriched in fragments of fresh, colorless and brown reactional volcanic glasses. During early diagenesis, the authigenous, weakly glauconitized, green smectitic material with mixed-layer structure (M-i) and small amounts of $\mathrm{K}, \mathrm{Fe}$-hydromica members was developed from acid volcanic glasses. The second product of the replacement of acid glasses was, as in Series II, zeolite from the heulandite group. Its formation was accompanied by initial glauconitization. The detritic material is represented by illite only. The rate of accumulation was so high (because of the influx of pyroclastics) that the clay oozes had no time to develop biogenic carbonate.

The sequence section at Hole 511 is topped by Oligocene deposits represented by clay-calcitic diatomites with small admixtures of volanic glass fragments in a few interlayers. The accumulated in a deep sea zone with high productivity of diatomaceous flora.

The assemblage of clay minerals in the diatomaceous sediments of Series $I$ is represented predominantly by intensely swelling, stable, mixed-layer (M-i) minerals, finely dispersed, and in composition near-smectites or smectites (in the lower part of Series I, Cores 10-20). These finely dispersed smectitic minerals were frequently formed from vitroclastic material in the presence of abundant reactive biogenic $\mathrm{SiO}_{2}$. However, smectitization was restricted by either lack of reactive $\mathrm{Al}_{2} \mathrm{O}_{3}$ or excessively high rates of accumulation of diatomic sediments (because of the high productivity of silicic organisms). In such conditions of sedimentation we can assume an influx of finely dispersed smectitic products brought by sea currents, along with fine particles of detritic illites and chlorites, from more remote areas. Thus the intensity of smectite concentration in the sediments was controlled by several factors, including the shape and dimensions of the basin, position of volcanic foci, and the direction of currents.

\section{The Argentine Basin, Holes 513 and 513A}

Holes 513 and 513A were drilled far from Hole 511 and their sequences cannot be directly controlled lithologically, because they are composed of deposits of different ages. The Site 513 sequence terminates in lower
Oligocene deposits, whereas Hole 511 begins with upper Oligocene sediments.

The sediments above basalt in the area of Site 513 accumulated in a deep sea environment. At the beginning, the basin was filled mainly by biogenic material with little admixture of clay matter. During the late Oligocene, biogenic material was represented predominantly by remains of coccoliths with persistent admixtures of biogenic $\mathrm{SiO}_{2}$, gradually increasing in time. At the very end of the Oligocene (beginning of the early Miocene), the latter exceeded the biogenic $\mathrm{CaCO}_{3}$ and the basin accumulated calcareous-siliceous sediments with average carbonate contents of about $42 \%$. Oceanographic conditions favored the development of calcitic microfauna in the surface waters, and this provided an enriched supply of biogenic $\mathrm{Ca}$.

The clays in these environments (Oligocene Series II) were accompanied by an influx of stable, nonswelling types (illite) and the development of assemblages of mixed-layer minerals (with sharply variable ratios between packets) from intensely swelling (M-i) up to weakly swelling (i-M) forms. The latter resulted possibly from the destruction of unstable trioctahedral micas from biotic series in the pelagic sediments. The small admixture of chlorite is represented by an $\mathrm{Mg}$, Fe-variety with "defective" brucitic layers. This mineral assemblage may have been formed after erosion of metamorphic rocks, possibly in the Antarctic, where they were widely exposed during this time.

At the end of the early Miocene, the influx of biogenic carbonate in this sedimentation basin almost stopped (its average content did not exceed $12 \%$ ), whereas the supply of biogenic silica and clay material increased. Such a sharp change in sediment composition possibly resulted from a corresponding climatic evolution: the climate undoubtedly became gradually cooler and remained so from the end of the Pliocene through the Pleistocene. Terrigenous, polymictic, clastic material was ice-rafted throughout the study area.

Clay formation during this period (Miocene-PliocenePleistocene Series I) was accompanied by a continuous influx of stable illite and mixed-layer (M-i) minerals with packets of Al-mica, as well as by the formation of montmorillonite altered from fine volcaniclastics in the presence of abundant amorphic $\mathrm{SiO}_{2}$.

\section{CONCLUSIONS}

The history of the accumulation of the sedimentary mantle in the Falkland Plateau, as interpreted from the most complete sequence at Site 511 , is subdivided into two large stages of sedimentation. Each of these stages is characterized by specific conditions of sediment accumulation.

The first stage, primarily Mesozoic, is characterized by shallow water marine sedimentary genesis. Sediments accumulated in semiclosed basins of the transitional zone among the contiguous continents (South America, Southern Africa, and Antarctica). This stage corresponds to four successive facies zones. Changes in types of sedimentation were controlled by the variations of 
climate, ratio between the terrigenous and organic matter supplied, fluctuations of salinity depending on the degree of closure of the basin (judging by gypsification of some sediments), and local erosion or more considerable hiatuses in the sedimentary record. Those changes are limited almost entirely to the transitional zone, not exceeding a depth of $2000-3000$ meters.

The second, predominantly Cenozoic stage is characterized by the formation of normal pelagic sediments in the open ocean. The main factors that controlled sedimentation in this zone were tectonic subsidence of the oceanic floor, fluctuation of the Antarctic Polar Front, and episodic volcanism

The structure and composition of the rocks recovered in the study area contain some evidence indicative of the evolution of the paleoclimate on the land then adjacent to the ocean. Thus, it may be assumed that during the formation of the Upper Jurassic and Barremian-Aptian sediments of Series VI and VIII, warm and humid climate provided conditions favorable to the accumulation of organic matter. Sediments formed that gave rise to the black shale series. During the Albian-Cenomanian, when Series V deposits were formed, the climate became more arid, although it still remained rather warm. Among sediments, the most predominant were detritalorganogenous-carbonate sediments, light in color and stained with $\mathrm{Fe}$-hydroxide. From the Turonian up to the Campanian and the beginning of the Maestrichtian, the climate turned more humid and the temperature became moderate. At this time gray clay sediments, low in carbonate, accumulated. The period of the Campanian to early Maestrichtian and up to the beginning of the Cenozoic was probably characterized by some warming and possibly increasing dryness of climate. Light coccolith-foraminiferal sediments accumulated. From the end of the early Miocene up to the Pleistocene (according to the sequence at Site 513) the climate was cool and moderately humid. A thick, homogeneous series of claydiatomaceous sediments, low in carbonate, accumulated.

Data on the mineralogy of the clay fraction from Leg 71 show that the evolution of environments in which the lithologic facies were deposited was distinctly reflected in the nature and structure of the clay minerals. For example, predominantly allochthonous assemblages of clay minerals accumulated in the shallow marine basins of the Jurassic to Early Cretaceous, except for authigen- ic smectitization in the presence of abundant organic matter in the black shales (Series VI). In contrast, the second, deep sea stage, in which biogenic (siliceous) sedimentation predominated, was accompanied by distinct authigenic clay formation: for example smectitization with zeolitization after vitroclastic material, and initial glauconitization of smectites.

The Site 513 sequence in the Argentine Basin overlaps and extends in time beyond that recovered at Hole 511, from the late Oligocene up to the Pleistocene inclusively. Its oceanic macrofacies is subdivided into two series: the facies of the carbonate Oligocene sediments with a number of mixed-layer minerals from $\mathrm{M}-\mathrm{i}$ up to $\mathrm{i}-\mathrm{M}$ and the series of siliceous, diatomic oozes (the upper Miocene and Pliocene) with more smectite.

The clay mineral assemblages in Cenozoic sediments of the Argentine Basin show a distinct predominance of illites (about 50-60\%), whereas Mesozoic sediments of the Falkland Plateau are predominantly composed of smectites or related mixed-layer (M-i) minerals, with the illite-chlorite total no greater than $15-20 \%$.

\section{REFERENCES}

Barker, P. F., Dalziel, I. W. D., et al., 1977. Init. Repts. DSDP, 36: Washington (U.S. Govt. Printing Office).

Drits, V. A., and Sakharov, B. A., 1976. X-ray structural analysis of mixed-layer minerals. Trans. GIN Acad. Sci., 295:1-271. (In Russian)

Gradusov, B. P., 1975. Minerals with Mixed-layer Structure in Soils: Moscow (Bauka). (In Russian)

Krasheninnikov, V. A., and Basov I. A., 1981. Geological history of the Falkland Plateau in the Mesozoic and Cenozoic. Geology of the Ocean Floor from Deep Sea Driling Data: Moscow (Nauka), pp. 24-25. (In Russian)

MacEwan, D. M., 1949. Diffraction X-ray in disordered mixed-layer structures: Soil clays. J. Soil Sci., 1:90-103.

Reynolds, R. C., 1968. The effect of particle size on apparent lattice spacing. Acta Crystalogr., 24.

Timofeev, P. P., 1969. Geology and facies of Jurassic coal-bearing formation of South Siberia. Trans. GIN Acad. Sci., 197:7-389 (In Russian)

Timofeev, P. P., Rateev, M. A., and Rengarten, N. V., 1979. Mineralogy of the clay fraction of the Atlantic Ocean sediments. In Montadert, L., Roberts, D. G., et al., Init. Repts. DSDP, 48: Washington (U.S. Govt. Printing Office), 1091-1097.

Trimonis, E. S., 1981. History of terrigenous sedimentation in the South Atlantic during Mesozoic-Cenozoic time. Geology of the Ocean Floor from Deep Sea Drilling Data: Moscow (Nauka), pp. 40-42. (In Russian) 